\section{Manchester merger set to proceed as southerners go solo}

\section{David Adam, London}

To merge or not to merge? That is the question on which British universities can't appear to make up their minds.

While the heads of Imperial College and University College London (UCL) were dodging the slings and arrows of outraged staff, those at the University of Manchester and the University of Manchester Institute of Science and Technology (UMIST) have calmed their sea of troubles sufficiently to start ordering new stationery.

The governing councils of both Manchester and UMIST have now given their blessing to a merger that could be completed as soon as autumn 2004 (see Nature 416, 114; 2002). Officials at both argue that the move will create "a truly world-class" institution in Manchester.

But for UCL and Imperial, the nuptials are well and truly cancelled. In statements issued on 18 November, the colleges said that following "an intense period of deliberation" they concluded that "the best interests of the two institutions are not served by a formal merger".

The London colleges first announced in October that they were considering joining forces to form a behemoth with twice the research income of Oxford and Cambridge universities (see Nature 419, 658, 2002; and Correspondence, page 359 of this issue). The colleges' heads, Richard Sykes at Imperial and Derek Roberts at UCL, argued that a merged institution would also be more globally competitive.

But critics were quick to pour scorn on the plans, which many staff and students at UCL viewed more as a takeover than a union of equals. UCL pharmacologist David Colquhoun calls the proposal's collapse a victory for "e-democracy" hundreds of researchers signed online petitions opposing the merger, and both staff and students set up protest websites.

The student website even claimed the posthumous support of UCL founder

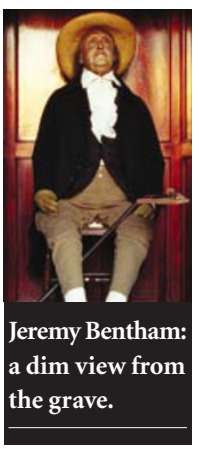
Jeremy Bentham, who died in 1832 and whose preserved remains are displayed at the college. It quotes him thus: "It was ever the case in this world, alas, that what has been painstakingly constructed over centuries may be reduced to rubble within moments."

\title{
Venter aims for maximum impact with minimal genome
}

Erika Check, Washington

Not for the first time, geneticist Craig Venter's latest wheeze has set US biology abuzz. This time he has reignited the debate over open publication of research results by declaring that he may not release all of the details of his new project.

On 21 November, Venter said he intends to synthesize a bacterial genome from scratch, and then insert it into a cell to see if it can direct the normal functions of the organism. Some observers claim that this process will effectively create a new life-form, but geneticists argue that Venter's project stops far short of this, because he will insert the genome into a naturally occurring, albeit modified, cell.

Venter also says that he may not publish the methods for this work, in case they were used to make biological weapons. "Depending on what is happening in this field, we may not disclose all these details," he says.

The planned work will build on an earlier project in bacterial genomics that he started at The Institute for Genomic Research in Rockville, Maryland. In that project, a team led by molecular geneticist Clyde Hutchison knocked out genes from a Mycoplasma genitalium bacterium one by one, and then estimated how many of the bacterium's 517 genes are required for it to live. The researchers estimated that about the bacterium needs about 300 genes to survive (C. A. Hutchison et al. Science 286, 2165-2169; 1999).

Venter's new project will also focus on what constitutes a 'minimal genome'. His approach will be different, however: he intends to construct a minimal Mycoplasma genome by building its chromosome from scratch. Scientists at Venter's Institute for Biological Energy Alternatives will use chemical synthesizers to manufacture the genes that should be required for Mycoplasma to live. Earlier this year, Eckard Wimmer of the State University of New York at Stony Brook used a similar technique to create an infectious poliovirus, which is much simpler than a bacterium (J. Cello, A. V. Paul and E. Wimmer, Science 297, 1016-1018; 2002). But Venter plans to take this process a step further, by putting the genes into a Mycoplasma cell with the original genetic material removed, to see if the new chromosome works.

If all goes according to plan, Venter will attempt to add further genes to turn the minimal Mycoplasma into something useful perhaps a fuel or an agent for environmental remediation. The US Department of Energy has given his alternative energy institute $\$ 3$ million over three years to work towards this goal, and Venter has hired Nobel laureate Hamilton Smith, who worked with him at

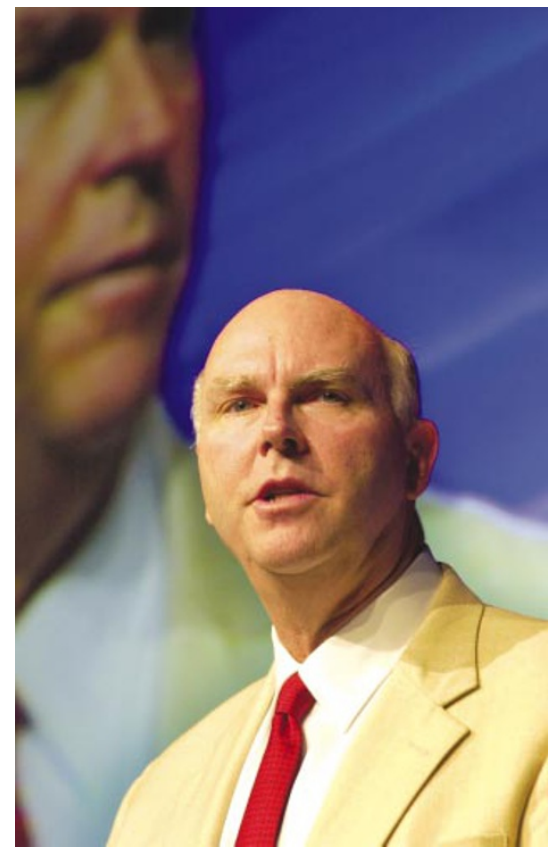

God news? Critics of Craig Venter's project claim that he is planning to create a new form of life.

Celera Genomics, to lead the project.

The proposed task will be difficult, but not impossible, scientists commented last week. They said that Venter's main challenges will be synthesizing long, accurate stretches of DNA, and putting the finished synthetic chromosome into a cell.

Most dismissed claims that Venter is playing God by trying to create a new kind of organism. "Geneticists have been trying to get existing life forms to do things they wouldn't ordinarily do for a long time, and it's called genetic engineering," said George Weinstock, co-director of the Human Genome Sequencing Center at Baylor College of Medicine in Houston, Texas.

But some cried foul at statements made by Venter to the effect that he might not publish full details of his methods. Earlier this year, he strongly criticized Wimmer's group for publishing the details of its work (see Nature 418, $265 ; 2002$ ). Venter stands by his criticism of that project, but says that "the community needs to be cautious" about what it publishes.

Venter's critics argue that he should not restrict publication without consulting the wider scientific community. "It's not for him to say," says Fred Blattner, a geneticist at the University of Wisconsin-Madison who is constructing minimal genomes in the bacterium Escherichia coli. "He ought to fall on the side of releasing the data unless a consensus develops that he shouldn't do it." 